\title{
CARBON CYCLING AT THE LANDSCAPE SCALE: THE EFFECT OF CHANGES IN CLIMATE AND FIRE FREQUENCY ON AGE DISTRIBUTION, STAND STRUCTURE AND NET ECOSYSTEM PRODUCTION
}

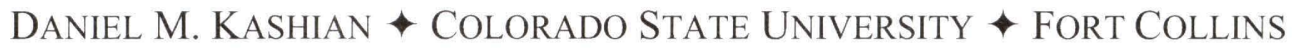 \\ Michael G. RyAn $\downarrow$ USDA Forest SERVICE $\downarrow$ ForT COLLINS \\ William H. ROMME $\uparrow$ COLORADO STATE UNIVERSITY $\uparrow$ FORT COLLINS \\ DANIEL B. TINKER \UNIVERSITY OF WYOMING $\downarrow$ LARAMIE \\ MONICA G. TURNER \UNIVERSITY OF WISCONSIN-MADISON $\downarrow$ MADISON
}

\begin{abstract}
$\downarrow \quad$ BACKGROUND AND OBJECTIVES
Climate, fire frequency and intensity, and forest structure and development are strongly linked, and predicting potential changes in carbon storage depends on understanding these links. However, we lack the ability to make robust predictions about how changes in climate will alter these interactions and change the carbon balance of a landscape. Forests contain as much as $80 \%$ of the total carbon stored aboveground and $40 \%$ of that stored belowground in terrestrial ecosystems (Dixon et al. 1994, Harmon 2001). Disturbances such as fires or insect outbreaks - controlled largely by climate - may shift a forested area from a net sink to a net source of carbon to the atmosphere, and increasing the frequency of large disturbances may affect the global carbon budget. Complex interactions among climate, disturbance regimes, and stand-level ecosystem processes, however, preclude predicting the importance of climate change for forest landscapes.
\end{abstract}

Carbon cycling in forests is a complex process affected by many factors. Carbon storage on landscapes is controlled by the balance between carbon accumulating in live biomass and the forest floor and carbon being lost though decay of dead wood (Kasischke et al. 1995); the distribution of stand ages on a landscape, since carbon stored in live and dead pools varies with stand development (Harmon 2001); and the distribution of stand structures on landscapes (Kashian et al. in review). Disturbance severity and frequency affect the proportional distribution of carbon among various pools, and may affect the distributions of stand ages on a landscape (Schoennagel et al. 2003). Moreover, rates of carbon accumulation may differ strongly following wildfires depending on fire severity (Wirth et al. 2002). Any change in climate that increases fire frequency or severity, and any change in fire regimes that alters the stand and structure distributions on landscapes, may therefore result in a shift of the landscape towards becoming a long-term carbon source.

Our current work in Yellowstone is examining how initial post-fire structural heterogeneity controls carbon dynamics over the full 
cycle of individual forest stands, and how climatemediated changes in the fire regime could potentially alter the behavior of the entire Yellowstone ecosystem as a net sink of net source in the global carbon cycle. Our main objective is to estimate how changes in fire frequency, pattern, and intensity will alter the distribution of forest age and structure across a landscape and how these changes, in turn, will affect the landscape carbon balance.

\section{$\uparrow \quad$ MeTHODS}

Our research will provide a detailed case study of carbon dynamics from the scale of individual forest stands to a large coniferous landscape. To meet this objective, we are describing changes in all of the major pools and fluxes of the carbon cycle at temporal scales ranging from years to centuries, as influenced by periodic fires and successional patterns within a landscape where fire frequency will likely accompany changes in global climate, and can potentially alter carbon cycling dramatically. By directly and indirectly quantifying all of the stocks and rates of change in the major components of the carbon cycle in the Yellowstone subalpine landscape, we will contribute to understanding how changes in disturbance regimes may produce qualitatively different patterns of carbon release and storage in coniferous forests worldwide.

\section{Field sampling}

Near-complete sampling of a complex and extensive field sampling plan that includes 77 stands across Yellowstone National Park was accomplished in 2004 and 2005. Three separate, replicated chronosequences were identified in the field. Each chronosequence included 3-5 stands sampled in five age classes: $<25$ years (stands sampled in Litton et al. 2004), 40-70, 80-130, 170-230, and >250. Chronosequences were constructed for low, medium, and high-density stands; stands $>170$ years old were sampled based on their recent history of bark beetles attacks rather than density. Thirty-one of the stands $>40$ years old were sampled previously by Kashian et al. (2005). All but four of the 77 stands were located within Yellowstone National Park; two were located in the Targhee National Forest, and two in Grand Teton National Park. Data were collected to quantify carbon pools in each stand in live biomass (using allometric equations developed in Yellowstone in 2004), dead wood, forest floor, soil, understory vegetation, and annual litterfall.
Each stand was sampled using three $10 \times 50$ $\mathrm{m}$ plots, with plots located at equal distances along a baseline. Belt transects in each plot were used to measure standing live and dead trees, stumps, and saplings, with transect width differing for overstory trees and saplings based on density. The center line of each plot was used to select trees and saplings for allometric measurement and to select locations for sampling soil and forest floor. Twenty-five randomly selected saplings in each plot were measured at the base. Ten mature trees were randomly selected for further sampling in each plot along the center line of each plot. For each tree, an increment core was extracted at breast height and the sapwood marked on the core, and tree height, height to crown base, and crown depth was measured. Finally, three dominant (oldest) live overstory trees were selected in each plot and an increment core extracted at the base for age determination.

Dead wood was measured using eight 50foot transects run due east from each plot; dead wood was tallied in five size classes, and classified for decay for the largest size class. Five forest floor samples approximately $900 \mathrm{~cm}^{2}$ in area were collected along the center line of each plot; all forest floor material was collected to the top of the mineral soil and composited by plot. A soil core was extracted to $30 \mathrm{~cm}$ from the top of the mineral soil within the area the forest floor was collected and separated into a $0-15 \mathrm{~cm}$ sample and a $15-30 \mathrm{~cm}$ sample. In 2004, twelve litter traps were deployed per stand to estimate annual litterfall, and ionexchange resin bags were deployed five per plot. Resin bags and litterfall were collected in July 2005; a second year of litterfall will be collected in July 2006.

Sampling of stands burned in 1988 follows the methods established by Litton et al. (2004). Coarse woody debris was sampled in all plots, including the 12 previously sampled by Litton et al. (2004). We also collected approximately 900 foliage samples from lodgepole pine in 42 stands in 2005 with the help of tree climbers for analysis of the variability of foliar nitrogen within and among trees and stands.

\section{Sample processing}

For each soil sample, fine roots were separated from soil, classified into live and dead roots, and weighed. A subsample of soil was then taken, rocks and non-root organic matter removed, and weighed, dried, and weighed again to determine bulk density. Live and dead roots were ground in a 
Wiley mill and analyzed for percent carbon. Soil samples were ground on a roller mill and also analyzed for percent carbon. Foliage, forest floor litter subsamples, litterfall, and coarse wood samples were ground in Wiley mills and analyzed for percent carbon and/or nitrogen. Increment cores were mounted and sanded per standard techniques. Tree ages were determined from each increment core, and the average 10-year ring width (used to estimate growth and productivity) was determined for each core using a sliding bench micrometer. As of the end of the 2005 field season, all field samples have been collected except for the second year's litterfall (to be collected in 2006).

\section{PRELIMINARY RESUlTS AND DISCUSSION}

Eight work-study students were hired for the fall of 2005 and spring of 2006 to process samples in the lab. As of February 28, all field samples (soil, fine roots, forest floor, coarse wood samples, and litterfall samples) have been processed and ground for analysis and about $50 \%$ of these samples have been analyzed for carbon and nitrogen.

The success of a project based on replicated chronosequences depends on the similarity of replicate stands within age classes and density classes in terms of total ecosystem carbon and the distribution of carbon among pools. The dead wood and forest floor pools exhibited higher variability than any other carbon pool $(\mathrm{CV}=51-79 \%)$, and this variability was most extreme in stands younger than 130 years. The proportion of carbon found in dead wood was most variable among replicates along the dense chronosequence, but this proportion was not significantly different among density classes. The coefficient of variation for carbon proportions for all other age classes was $<50 \%$.

Strong differences occur in carbon storage and distribution among pools with stand age and density. In all stands, total ecosystem carbon increases from $\sim 5000 \mathrm{~g} \mathrm{C} / \mathrm{m}^{2}$ in stands $<25$ years to a peak of about $14700 \mathrm{~g} \mathrm{C} / \mathrm{m}^{2}$ in stands $80-130$ years, then decreases thereafter. Such a trajectory suggests a rapid increase of carbon storage as forest growth exceeds decomposition of dead wood, then a loss of carbon as forest productivity slows and carbon lost through decomposition increases proportionately. The initial proportion of total carbon in live biomass is higher in stands $<25$ years as density increases, and the peak carbon storage is also higher in denser stands $(\mathrm{p}<0.03)$.

The proportion of total carbon in dead wood varied almost inversely with that found in live biomass. Dead wood represented significantly more total carbon in young stands $(>91 \% ; \mathrm{p}<0.05)$ than those aged $40-130$ years $(\mathrm{p}<0.02)$, and dead wood represented the least amount of total carbon in the 80130 class $(7-12 \%)$, although more carbon is found in dead wood in old stands $(p<0.05)$. Dead wood represented less than $27 \%$ of total carbon in all stand age and density classes except for young stands and old stands attacked by bark beetles (38\%). The proportion of total carbon in dead wood was significantly higher in low- and moderate-density stands than in dense stands $(\mathrm{p}<0.01)$, probably because higher rates of carbon accumulation occur in denser stands due to a higher leaf area.

\section{$\downarrow$ CONCLUSIONS}

Though preliminary, our results suggest that the balance between carbon gained through tree growth and carbon lost through decomposition of dead wood controls the ability of a stand to store carbon. This balance differs among stands of different ages and structures, and thus altering the distribution of stand ages and structures across a landscape - which may occur with changes in fire frequency - may result in a qualitative shift of the landscape between a carbon source or sink. We have not yet calculated the carbon balance of the stands we have sampled, focusing here only on carbon stocks. Relatively low levels of carbon stored in live biomass vs. deadwood in young stands, however, suggests that young stands are likely to lose more carbon through decomposition than they gain through photosynthesis (carbon sources), while middle-aged and older stands are likely to gain more carbon than they lose (carbon sinks). The current Yellowstone landscape, therefore, dominated by young stands following the 1988 fires, is probably a source of carbon to the atmosphere, though it will likely return to a carbon sink with time. An increase in the frequency of fires like those that occurred in 1988 is likely to reduce the amount of carbon stored on coniferous landscapes, however, which has strong implications for the global carbon budget. 


\section{ACKNOWLEDGEMENTS}

We thank the following undergraduates and graduate students who have faithfully collected field data for this project since 2004: Lauren Alleman, Rick Arcano, Caitlin Balch-Burnett, Lance East, Lance Farman, Deborah Fritts, Lisa Huttinger, Heather Lyons, Kellen Nelson, Therese Tepe, and Andy Whelan. We also thank those who have processed samples in the lab: Lauren Alleman, Carissa Aoki, Marc Barker, Jamie Brennan, Todd Hagadone, Tiann Heit, Chris Herron, Aliy Louie, Chris Martin, Valerie Miller, Tiffany Minton, Kellen Nelson, Kevin Rudzicka, and Ashlee Wallin. We especially thank Kellen Nelson and Heather Lyons, who were responsible for leading and supervising the field crews in 2004 and 2005.

\section{$\downarrow$ Literature Cited}

Dixon, R.K., S. Brown, R.A. Houghton, A.M. Solomon, M.C. Trexler and J. Wisniewski. 1994. Carbon pools and flux of global forest ecosystems. Science 263: 185-190.

Harmon, M.E. 2001. Carbon sequestration in forests: addressing the scale question. Journal of Forestry 99: 24-29.

Kasischke, E.S., N.L. Christensen and B.J. Stocks. 1995. Fire, global warming, and the carbon balance of boreal forests. Ecological Applications 5: 437-451.
Kashian, D.M., M.G. Ryan, W.H. Romme, D.B. Tinker and M.G. Turner. In review. Carbon storage on coniferous landscapes: Linking stand-replacing fire frequency, post-fire recovery, and ecosystem processes. Bioscience.

Kashian, D.M., M.G. Turner, W.H.Romme and C.G. Lorimer. 2005. Variability and convergence in stand structural development on a fire-dominated subalpine landscape. Ecology 86: 643-654.

Litton, C.M., M.G. Ryan and D.H. Knight. 2004. Effects of tree density and stand age on carbon allocation patterns in postfire lodgepole pine. Ecological Applications 14: 460-475.

Schoennagel, T., M.G. Turner and W.H. Romme. 2003. The influence of fire interval and serotiny on postfire lodgepole pine density in Yellowstone National Park. Ecology 84: 2967-2978.

Wirth, C., E.D. Schulze, B. Luhker, S. Grigoriev, M. Siry, G. Hardes, W. Ziegler, M. Backor, G. Bauer and N.N. Vygodskaya. 2002. Fire and site type on the long-term carbon and nitrogen balance in pristine Siberian Scots pine forests. Plant and Soil 242: 41-63. 